GORAN PEJIĆ, M.Sc. ${ }^{1}$

E-mail: goran.pejic@cvh.hr

FRANJO BIJELIĆ, M.Sc. ${ }^{1}$

(Corresponding author)

E-mail: franjo.bijelic@cvh.hr

GORAN ZOVAK, Ph.D. ${ }^{1}$

E-mail: goran.zovak@cvh.hr

ZORAN LULIĆ, Ph.D. ${ }^{2}$

E-mail: zoran.lulic@fsb.hr

${ }^{1}$ Center for Vehicles of Croatia

Capraška 6, 10000 Zagreb, Croatia

2 University of Zagreb

Faculty of Mechanical Engineering and Naval Architecture

Ivana Lučića 5, 10002 Zagreb, Croatia
Safety and Security in Traffic Preliminary Communication

Submitted: 26 July 2018

Accepted: 27 March 2019

\title{
MODEL FOR CALCULATING AVERAGE VEHICLE MILEAGE FOR DIFFERENT VEHICLE CLASSES BASED ON REAL DATA: A CASE STUDY OF CROATIA
}

\begin{abstract}
Mileage data collected via surveys based on self-estimation, reports from garages and other sources which use estimations are rough estimates and differ greatly from the actual mileage. Vehicle mileage is a major factor in emission calculations and needs to be as accurate as possible to obtain reliable emission models. Odometer readings are collected annually at the periodic technical inspection in Croatia. Average mileage data were analyzed for vehicles up to 20 years of age in 2017. Vehicles were classified by curb weight and fuel type. Such classification proved to follow driver behavior and the intended purpose of the vehicle. For each vehicle class the model was applied using vehicle age and population size as inputs for calculating average mileage. Real data show that vehicles in Croatia considerably exceed the estimated mileage in the years following the first registration of the vehicle and that they cannot be compared to data collected in other studies based on estimations. The difference lies in the covered mileage after vehicles reach ten years of age. The outcome of this study has resulted in a model for calculating average vehicle mileage. The model is suitable for use in various analyses for Croatia or for countries with similar driving habits and economic status now and for years to come.
\end{abstract}

\section{KEY WORDS}

average vehicle mileage; mileage model; periodic technical inspection;

\section{INTRODUCTION}

The transport sector contributes to one fourth of greenhouse gas emissions in the European Union and this figure is continuously rising. Most of these gas emissions originate from road transport [1]. Data used as input for creating emission models therefore need to be collected and analyzed [2]. These models study the effects of different transport and environment policies on the emissions of the transport sector, considering the costs and effects of a wide range of policy instruments and measures [3].

A major factor in emission calculations is vehicle average mileage, for which exact values are difficult to obtain or are often estimated $[4,5,6,7,8]$. Mileage data collected via surveys or by self-estimation are rough estimates and differ quite significantly from the actual mileage. Data collected in this way are not suitable as input data for finer emission analyses [9]. Information on fleet size is easier to obtain than mileage data. The goal of this study is therefore to find a model for calculating average vehicle mileage for different vehicle classes to make emission calculations more accurate and enable their use in transport-related calculations [10].

In Croatia, vehicle odometer readings are recorded at every periodic technical inspection (PTI), which is conducted on an annual basis. The Center for Vehicles of Croatia (CVH), a public authority managing the organization and standardization of PTI in Croatia, possesses an extensive vehicle database with odometer readings, which were used in this study. In Croatia, over two million PTI inspections were completed in 2017, with more than 1.5 million concerning passenger cars [11].

Road vehicles differ with regard to weight, size and intended purpose. In terms of their appearance characteristics, formal vehicle categories in Europe are only a rough guide in mileage calculation models. This is due to the wide range within a certain vehicle category, such as M1, which includes five-seater and 
nine-seater vehicles. Informal vehicle classification exists, which describes vehicles as mini, large etc. [12]. However, according to automotive environmental and safety type-approval requirements, and by defining the intended purposes of a vehicle, more appropriate categories can be obtained [13]. Emission calculations usually divide vehicles by their engine displacement size [14]. This study classifies vehicles taking into account type-approval categories and vehicle weight. Weight classes were formed based on the most frequent car make and type representatives relative to the non-formal European categorization. The chosen increment in vehicle weight classes corresponds to increased emissions emanating from them [15]. This paper explains how and why certain data were collected, with results shown separately for each vehicle class.

\section{METHODOLOGY}

The average mileage data were analyzed for vehicles up to 20 years of age in 2017. Vehicles were classified based on fuel type and curb weight. As opposed to engine displacement size, curb weight considers forced induction systems and engine downsizing. Category M1 passenger cars were divided into eight classes, with their class representatives shown in Table 1. The weight increments were formed based on the most frequent car make and type representatives relative to the non-formal European categorization. Vehicles in category $\mathrm{M} 1$, irrespective of being of the same make and type, can differ in weight depending on their trim level. Trim level denotes with what equipment the vehicle was delivered to the customer. All-wheel drive, automatic gearbox, body type etc. can greatly affect the vehicle curb weight, so for this study the weight of the basic trim models was chosen for model coefficients validation. Basic trims represent most of the vehicles sold in Croatia because of their lower price [5].

Table 1 - Vehicle classes for category M1

\begin{tabular}{|c|c|c|}
\hline Vehicle class & Curb weight [kg] & Fuel type \\
\hline \multicolumn{3}{|c|}{$\begin{array}{c}\text { Class representatives (all variants): Smart Fortwo, } \\
\text { Peugeot 107, Citroen (C1) }\end{array}$} \\
\hline M1 class 1 & $\leq 1000$ & Diesel \\
\hline M1 class 2 & $\leq 1000$ & Gasoline \\
\hline \multicolumn{3}{|c|}{$\begin{array}{l}\text { Class representatives (all variants): Volkswagen (Golf, } \\
\text { Polo), Toyota (Auris, Yaris), Ford (Focus, Fiesta) }\end{array}$} \\
\hline M1 class 3 & $1001 \leq 1400$ & Diesel \\
\hline M1 class 4 & $1001 \leq 1400$ & Gasoline \\
\hline \multicolumn{3}{|c|}{$\begin{array}{l}\text { Class representatives (all variants): Volkswagen (Passat) } \\
\text { Audi (A4), Opel (Insignia) }\end{array}$} \\
\hline M1 class 5 & $1401 \leq 1800$ & Diesel \\
\hline M1 class 6 & $1401 \leq 1800$ & Gasoline \\
\hline \multicolumn{3}{|c|}{$\begin{array}{l}\text { Class representatives (all variants): Opel (Antara), Audi } \\
\text { (A8), Mercedes (S Class) }\end{array}$} \\
\hline M1 class 7 & $>1800$ & Diesel \\
\hline M1 class 8 & $>1800$ & Gasoline \\
\hline
\end{tabular}

Commercial vehicles equipped with diesel engines were classified by their vehicle category, except for vehicles in category N1, which were additionally classified by their curb weight. Applying a weight limit to create classes in category N1 separated small delivery vehicles from small trucks. Commercial vehicles, category $\mathrm{N}$, were classified in four classes with their class representatives shown in Table 2.

Table 2 - Vehicle classes for category N1

\begin{tabular}{|c|c|c|}
\hline Vehicle class & Curb weight [kg] & Fuel type \\
\hline \multicolumn{3}{|c|}{$\begin{array}{l}\text { Class representatives (all variants): Volkswagen (Caddy), } \\
\text { Citroen (Berlingo), Nissan (NV200) }\end{array}$} \\
\hline N1 class 1 & $\leq 1800$ & Diesel \\
\hline \multicolumn{3}{|c|}{$\begin{array}{c}\text { Class representatives: Fiat (Ducato), Citroen (Jumper), } \\
\text { Mercedes (Sprinter) }\end{array}$} \\
\hline N1 class 2 & $>1800$ & Diesel \\
\hline \multicolumn{3}{|c|}{$\begin{array}{c}\text { Class representatives (all variants): Iveco (Daily), } \\
\text { Mercedes (Atego) }\end{array}$} \\
\hline N2 class & $\begin{array}{c}\text { Maximum } \\
\text { permissible mass } \\
\text { (by vehicle category) }\end{array}$ & Diesel \\
\hline \multicolumn{3}{|c|}{$\begin{array}{l}\text { Class representatives: Man (TGA), Mercedes (Actros), } \\
\text { Iveco (Trakker) }\end{array}$} \\
\hline N3 class & $\begin{array}{c}\text { Maximum } \\
\text { permissible mass } \\
\text { (by vehicle category) }\end{array}$ & Diesel \\
\hline
\end{tabular}

For each class, mileage data were taken from the database. The analysis was done on the entire vehicle fleet in Croatia in 2017. Mileage records containing unrealistic data were discarded. These include mileage values equal to 0 or a negative difference in mileage for a specific vehicle in two consecutive years. A third-degree polynomial analysis was then applied to the data as shown in Equation 1. At the beginning of their life cycle, vehicles achieve the highest annual mileage. The mileage tends to even out in the middle of the life cycle and starts dropping slowly toward the end. Actual vehicle operation is described best by a third degree polynomial for this reason.

$$
y=C 1 x^{k}+C 2 x^{k-1}+C 3 x^{k-2}+b
$$

$$
\begin{array}{ll}
y & \text { - average mileage for a specific year } \\
x & \text { - vehicle age }
\end{array}
$$

$C 1, C 2, C 3$ - polynomial coefficients

$k \quad$ - third degree polynomial

$b \quad$ - constant, closely representing achieved mileage in the first year

To validate the resulting model coefficients based on the fleet size in a certain class, smaller randomly chosen samples were taken from the fleet as class representatives. Each representative is unique when considering the population size, number of car manufacturers and models and different price ranges. Some vehicle class representatives are missing because there were none which reoccur in the vehicle fleet for all ages. Finally, the resulting model was compared to an existing one [16]. 


\section{RESULTS}

A third degree polynomial regression was applied for each vehicle class mileage data described in Tables 1 and 2 to average mileage data of 2017. Each class also shows average mileage for 2014, and for some vehicle classes the average mileage for a random chosen class representative is also shown.

\subsection{Model applied to M1 class 1}

Applying a polynomial regression of the third order $(k=3)$ for the M1 class 1 resulted in an equation with an $R^{2}$ value of 0.7346 . The model applied to M1 class 1 is shown in Figure 1 and in Equation 2.

$$
y=-3.9392 x^{3}+160.95 x^{2}-2414.9 x+24738
$$

The fleet size in this vehicle class for vehicles up to four years old is small, which is why the model does not reflect the acquired data but is still acceptable. Data for 2014 display the repeatability of the covered mileage in the recent period. This phenomenon occurs for a few reasons, one of which is that a certain vehicle class is used for the same tasks and is mostly driven by a certain group of people.

\subsection{Model applied to M1 class 2}

Applying a polynomial regression of the third order $(k=3)$ resulted in an equation with an $R^{2}$ value of 0.9893 . The model applied to M1 class 2 is shown in Figure 2 and in Equation 3.

$y=-1.6096 x^{3}+61.626 x^{2}-920.56 x+14141$

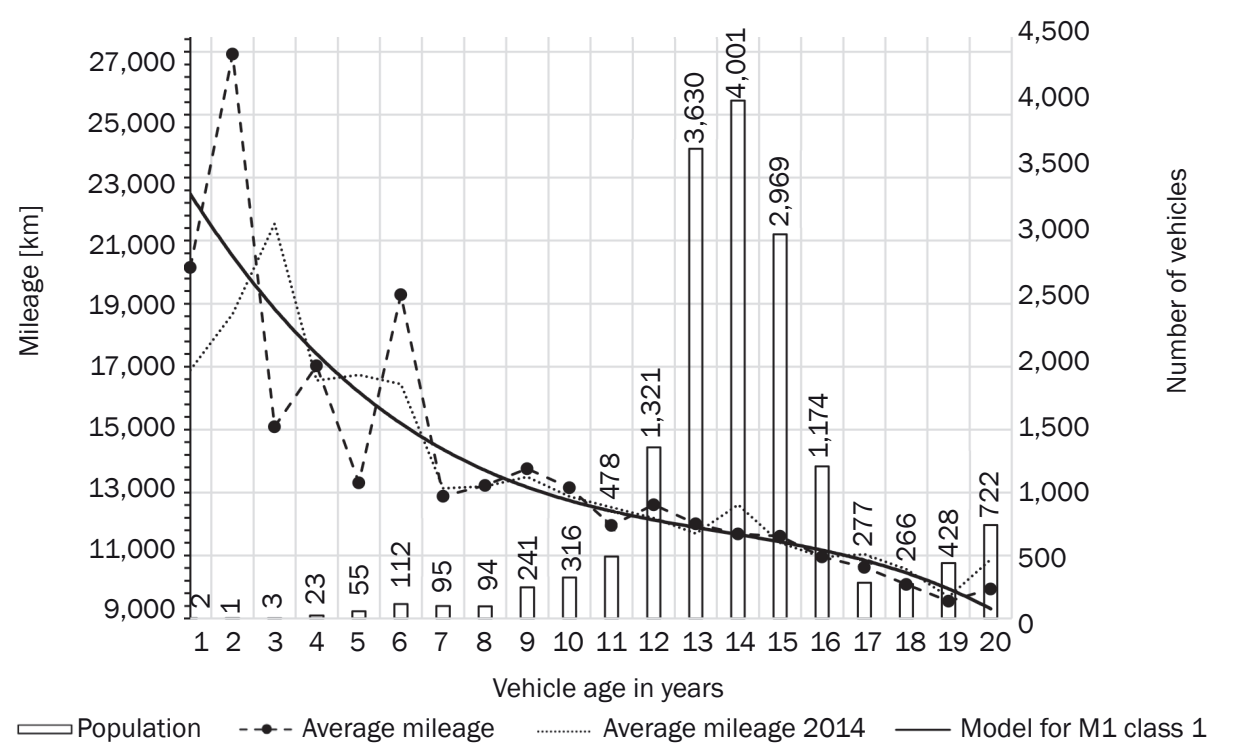

Figure 1 - Average vehicle mileage for category M1 class 1

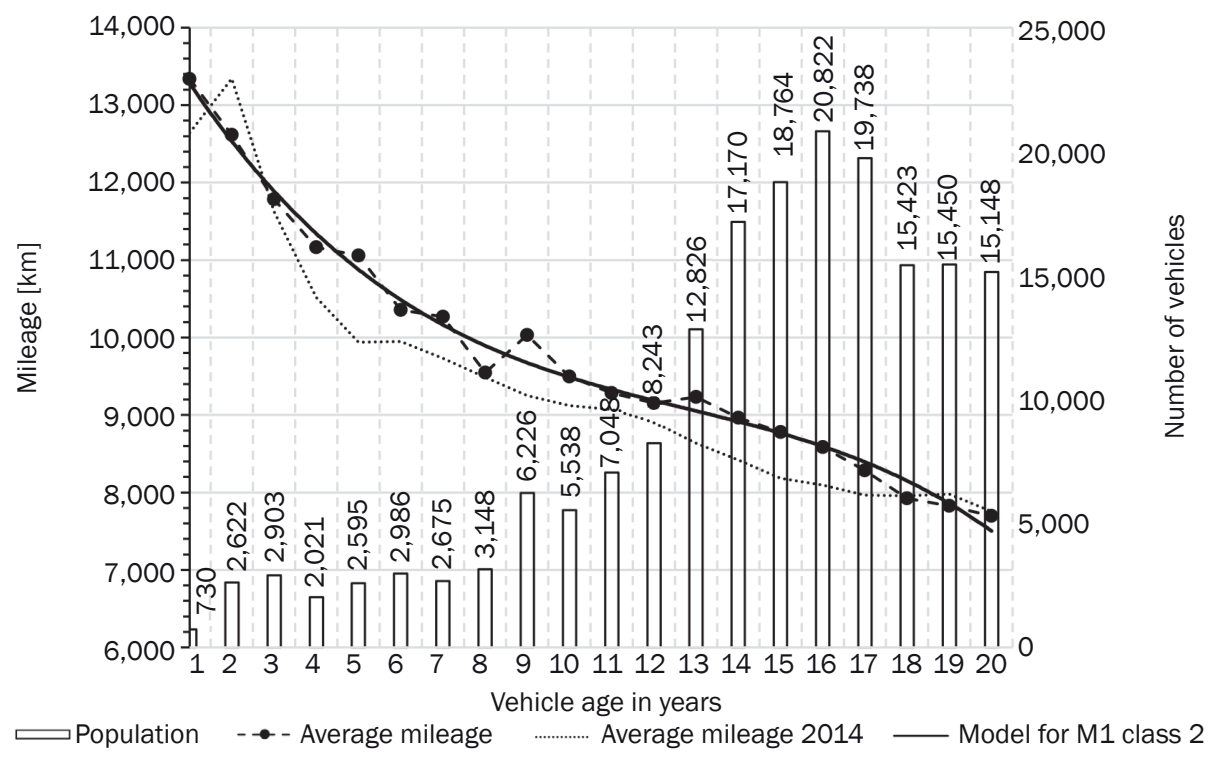

Figure 2 - Average vehicle mileage for category M1 class 2 
The model closely describes actual data with two noticeable slopes. At the beginning of their life cycle, the vehicles achieve the highest annual mileage. The mileage tends to even out in the middle of the life cycle and starts dropping slowly toward the end.

\subsection{Model applied to M1 class 3}

Applying a polynomial regression of the third order $(k=3)$ resulted in an equation with an $R^{2}$ value of 0.974 . The model applied to M1 class 3 is shown in Figure 3 and in Equation 4.

$y=-1.456 x^{3}+78.068 x^{2}-1576.9 x+24575$

The resulting model applied to M1 class 3 is similar to M1 class 2. There is a noticeable drop in fleet size of vehicles aged up to nine years, which corresponds to the period of the global economic crisis. The average vehicle age for passenger cars in Croatia is over 13 years, which corresponds to the highest fleet size around that age. The specimen for the M1 class 3 is Volkswagen Golf, and the results for 2014 show its validity.

\subsection{Model applied to M1 class 4}

Applying a polynomial regression of the third order $(k=3)$ resulted in an equation with an $R^{2}$ value of 0.9836 . The model applied to M1 class 4 is shown in Figure 4 and in Equation 5.

$y=-0.6146 x^{3}+27.859 x^{2}-601.17 x+14526$

The resulting model applied to M1 class 4 is similar to $\mathrm{M} 1$ class 2 . Again, there is a noticeable drop in the number of vehicles aged up to nine years, which

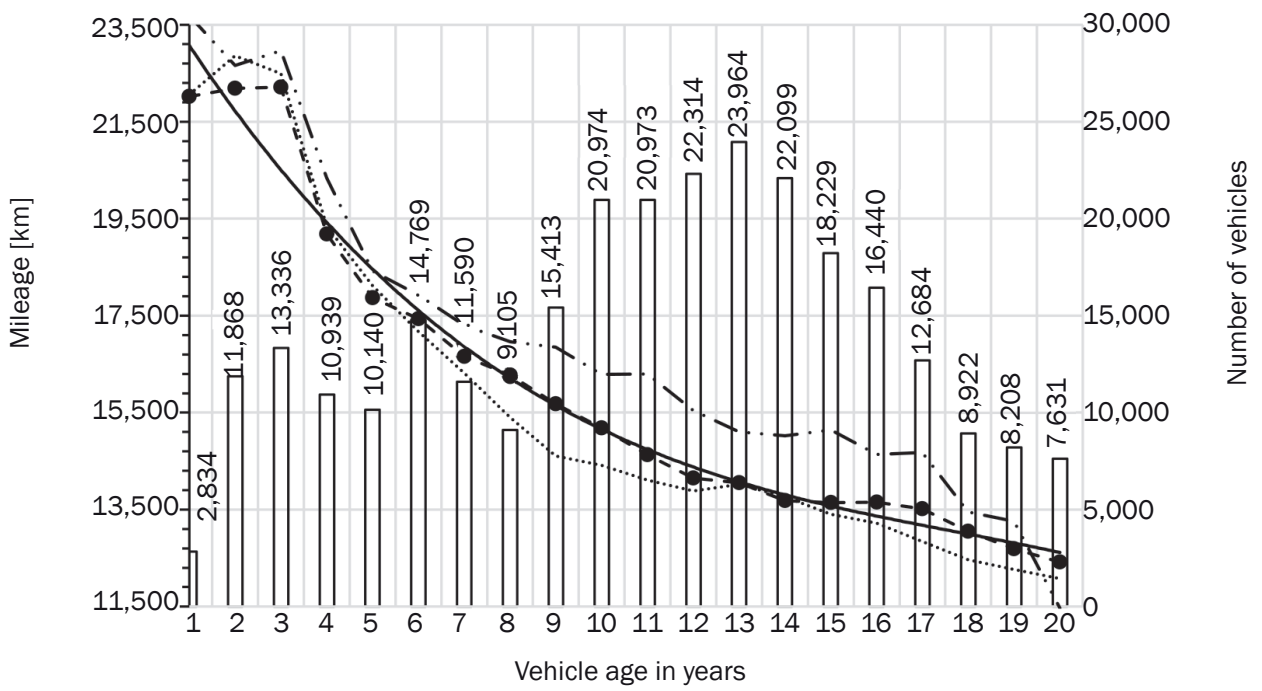

$\Longleftarrow$ Population $\quad \rightarrow-$ - Average mileage …….... Average mileage $2014 \quad$ - -.- Specimen - Volkswagen Golf — Model for M1 class 3

Figure 3 - Average vehicle mileage for category M1 class 3

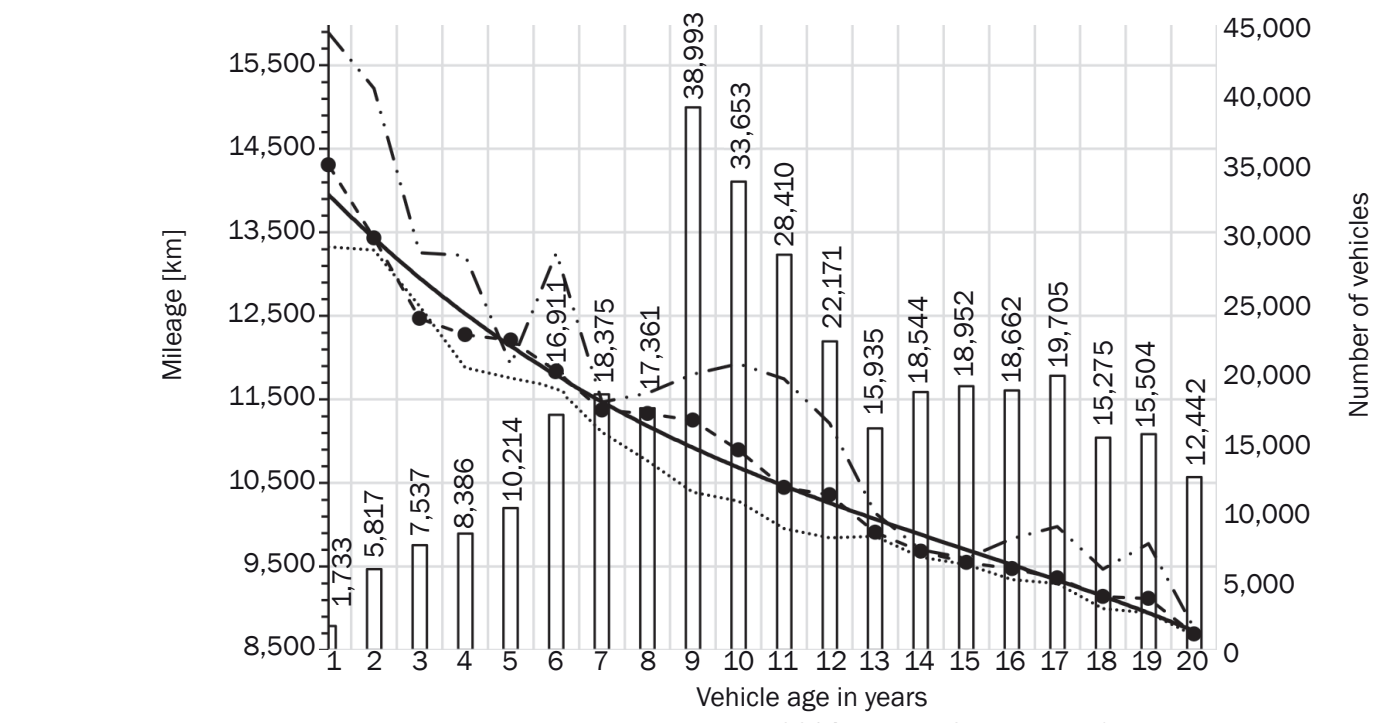

$\Longleftarrow$ Population $\quad \rightarrow$ - Average mileage $\quad \cdots . . \cdots \cdots . .$. Average mileage $2014 \quad-\cdots-$ Specimen - Opel Astra

_ Model for M1 class 3

Figure 4 - Average vehicle mileage for category M1 class 4 
corresponds to the global economic crisis. The specimen for the M1 class 4 is Opel Astra, and the results for 2014 show its validity.

\subsection{Model applied to M1 class 5}

Applying a polynomial regression of the third order $(k=3)$ resulted in an equation with an $R^{2}$ value of 0.9828 . The model applied to M1 class 5 is shown in Figure 5 and in Equation 6.

$$
y=-3.2163 x^{3}+125.85 x^{2}-1883.3 x+26460
$$

The resulting model applied to M1 class 5 is similar to M1 class 2. Although the economic crisis again had its impact on the size of the vehicle fleet, this vehicle class managed to recover because of its popularity in Croatia. The specimen for the M1 class 5 is Volkswagen Passat, and the results for 2014 show its validity.

\subsection{Model applied to M1 class 6}

Applying a polynomial regression of the third order $(k=3)$ resulted in an equation with an $R^{2}$ value of 0.964 . The model applied to M1 class 6 is shown in Figure 6 and in Equation 7.

$y=1.4074 x^{3}-36.542 x^{2}-164.26 x+15788$

The resulting model applied to M1 class 6 is similar to $\mathrm{M} 1$ class 2.

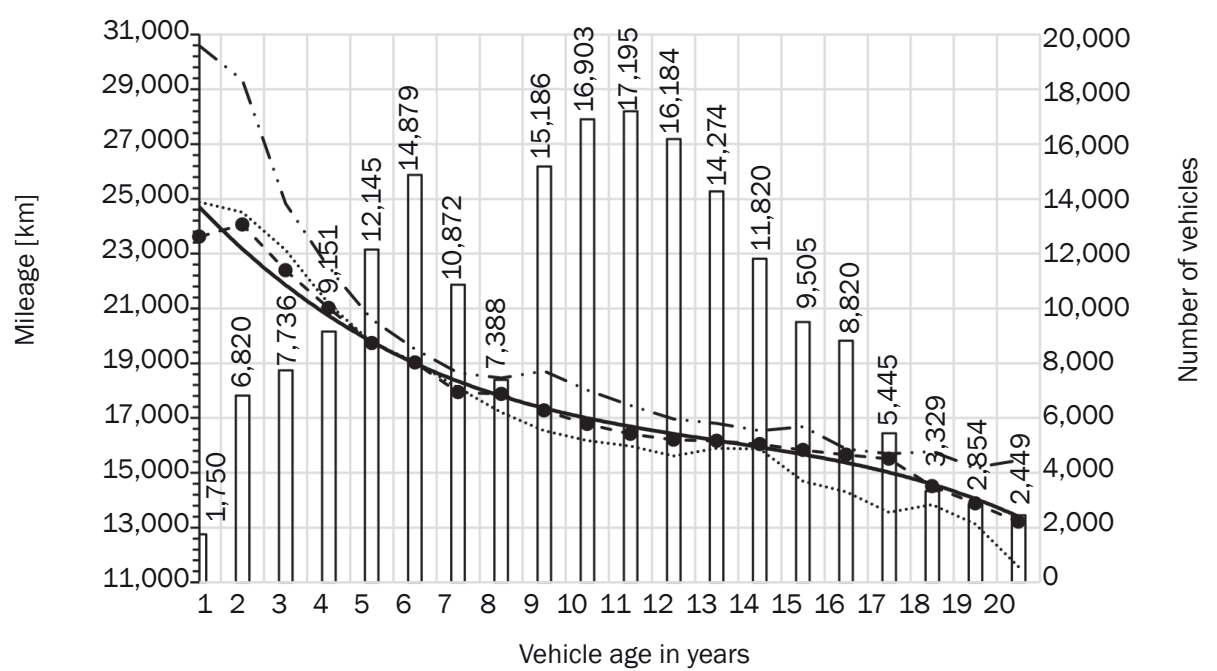

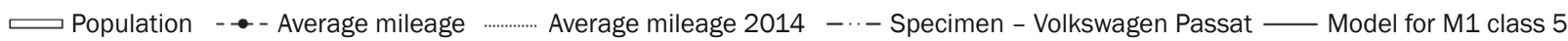

Figure 5 - Average vehicle mileage for category M1 class 5

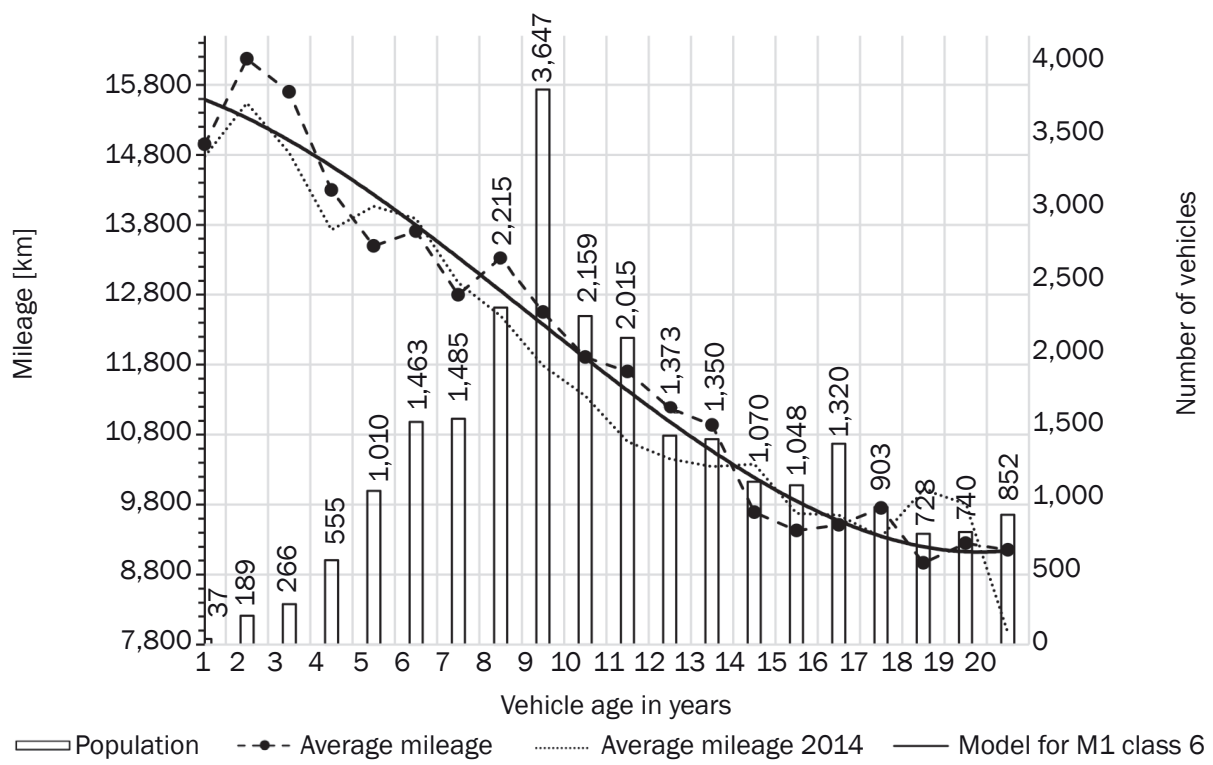

Figure 6 - Average vehicle mileage for category M1 class 6 


\subsection{Model applied to M1 class 7}

Applying a polynomial regression of the third order $(k=3)$ resulted in an equation with an $R^{2}$ value of 0.9903. The model applied to M1 class 7 is shown in Figure 7 and in Equation 8.

$y=-0.8547 x^{3}+59.313 x^{2}-2014.7 x+34117$

The resulting model closely describes real data with two slopes visible. Vehicles in this class are usually owned by companies, which is why their numbers were affected by the global crisis.

\subsection{Model applied to M1 class 8}

Applying a polynomial regression of the third order $(k=3)$ resulted in an equation with an $R^{2}$ value of 0.9471 . The model applied to M1 class 8 is shown in Figure 8 and in Equation 9.

$y=-4.5403 x^{3}+184.2 x^{2}-3000.4 x+28225$

Again, vehicles in this class are usually owned by companies in the first few years of their life cycle, which is the reason for a sudden mileage drop after a few years. The mileage tends to even out in the middle

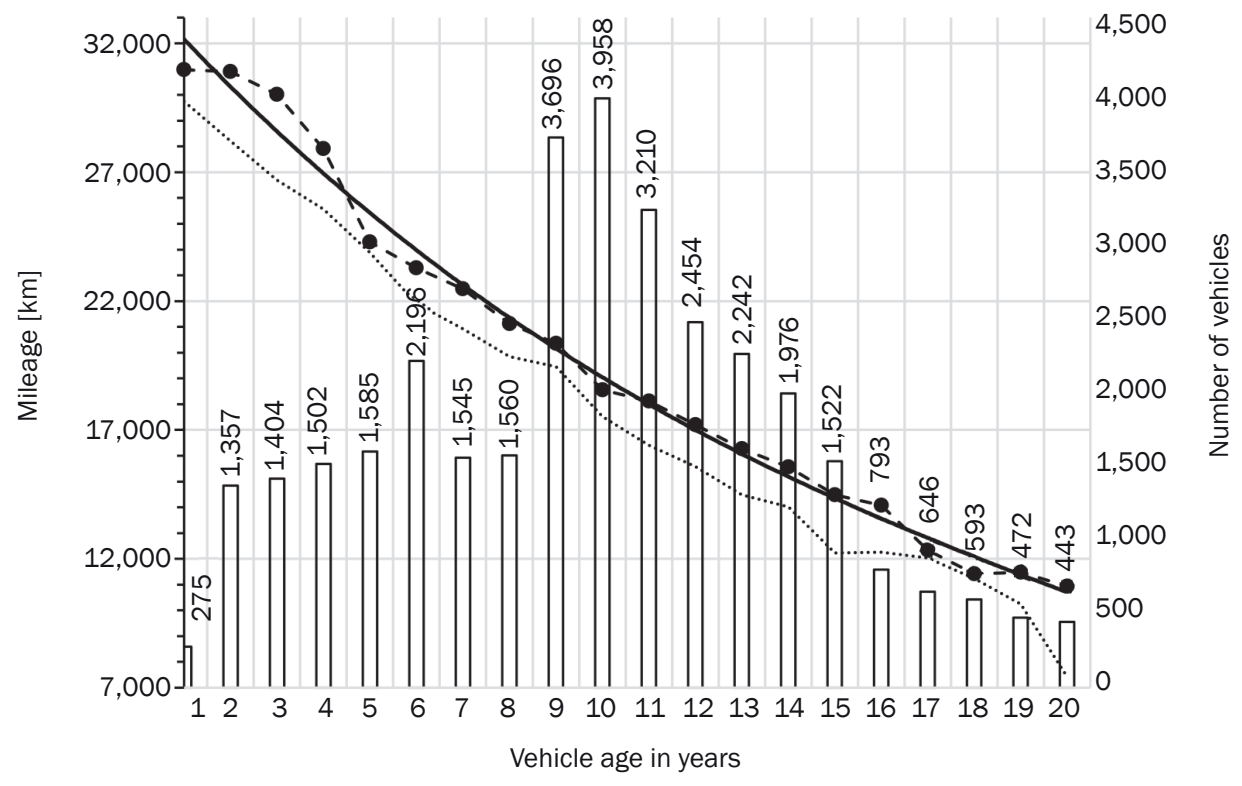

ऍPopulation $\quad-\rightarrow$ - Average mileage …….... Average mileage $2014 \quad$ Model for M1 class 7

Figure 7 - Average vehicle mileage for category M1 class 7

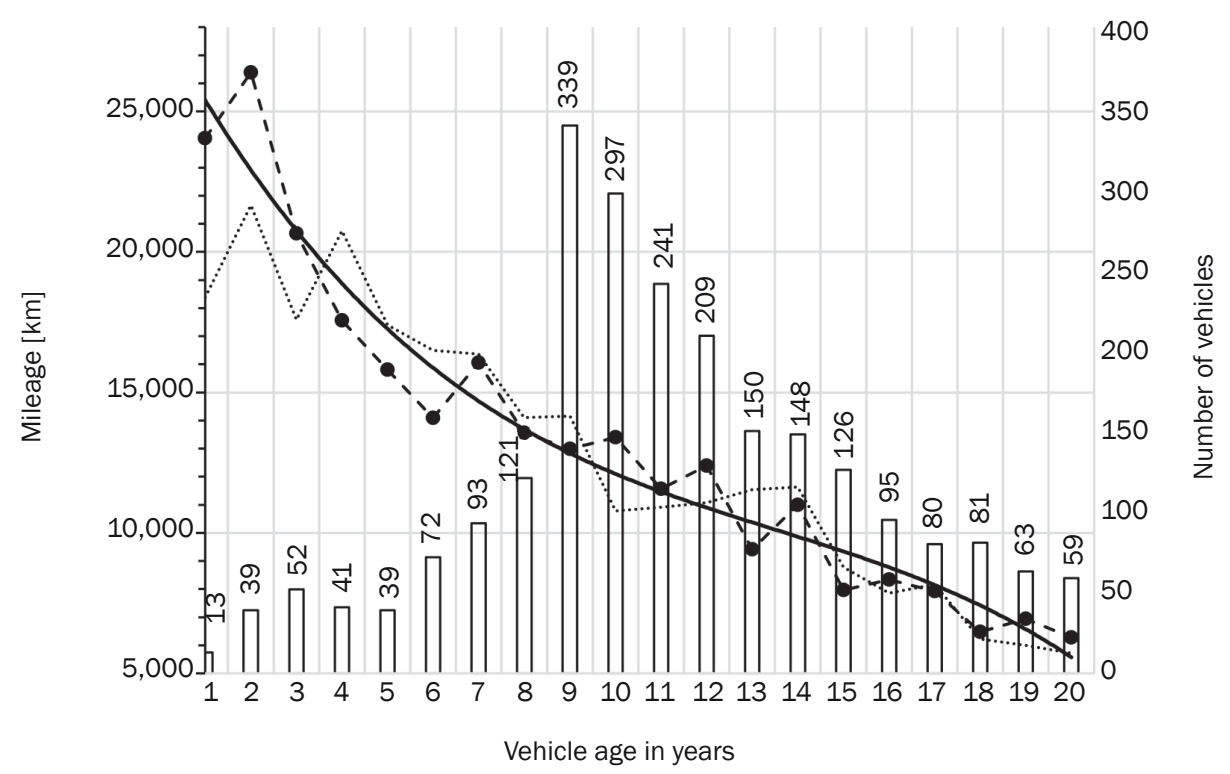

एPopulation $\quad \rightarrow-$ - Average mileage $\quad$............. Average mileage $2014 \quad$ Model for M1 class 8

Figure 8 - Average vehicle mileage for category M1 class 8 
of the life cycle when the vehicles are bought from the companies and starts dropping slowly toward the end of it. This is by far the smallest vehicle class and represents the executive car market.

\subsection{Model applied to N1 class 1}

Applying a polynomial regression of the third order $(k=3)$ resulted in an equation with an $R^{2}$ value of 0.9854 . The model applied to $\mathrm{N} 1$ class 1 is shown in Figure 9 and in Equation 10.

$y=5.8657 x^{3}-158.51 x^{2}+95.799 x+29127$

The resulting model is similar to the M1 class 2 in its shape but with added covered mileage as these are commercial vehicles. Again, there is a noticeable drop in the number of vehicles visible in vehicles aged exactly 8 years, which corresponds to the global world crisis. The number starts growing again because, unlike passenger cars, this vehicle class is used in everyday business. The specimen for the N1 class 1 is Volkswagen Caddy, and the results for the year 2014 show its validity.

\subsection{Model applied to N1 class 2}

Applying a polynomial regression of the third order $(k=3)$ resulted in an equation with an $R^{2}$ value of 0.9901 . The model applied to N1 class 2 is shown in Figure 10 and in Equation 11.

$$
y=-0.3725 x^{3}+85.371 x^{2}-3046.7 x+44789
$$

This vehicle class, best known as vans, is almost exclusively used for goods transportation. When these vehicles are new, owners utilize their investment to its

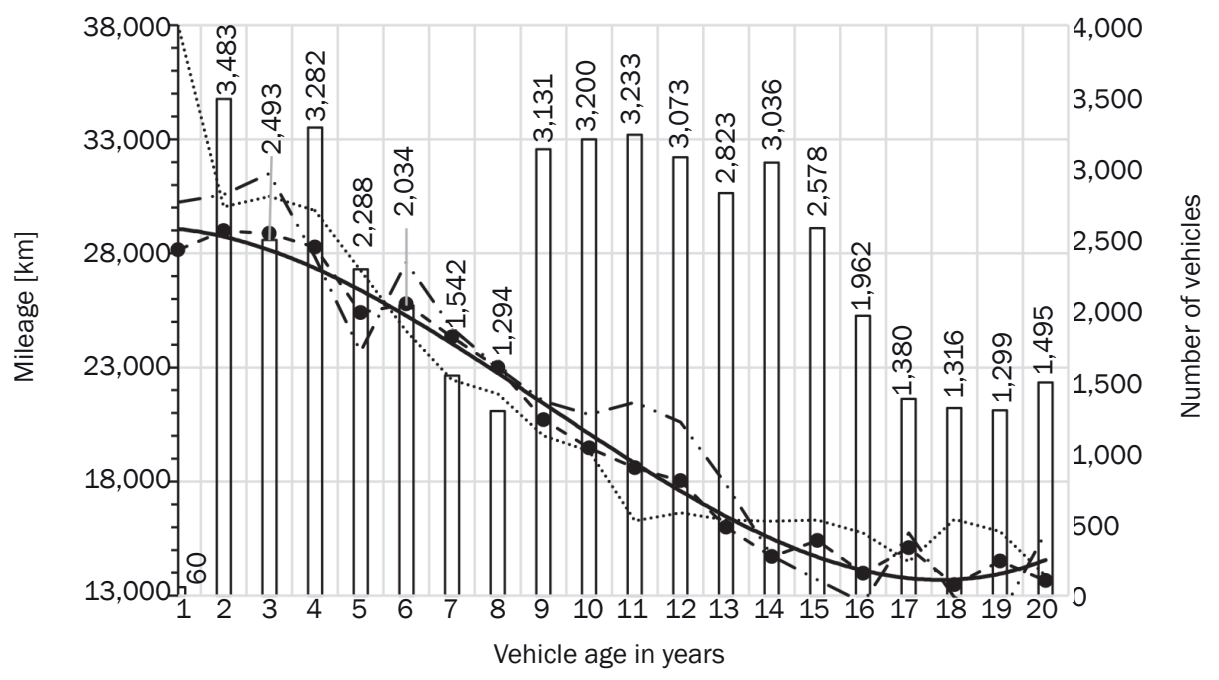

$\Longleftarrow$ Population - $\rightarrow$ - Average mileage ............ Average mileage 2014 - -.- Specimen - Volkswagen Caddy — Model for N1 class 1

Figure 9 - Average vehicle mileage for category N1 class 1

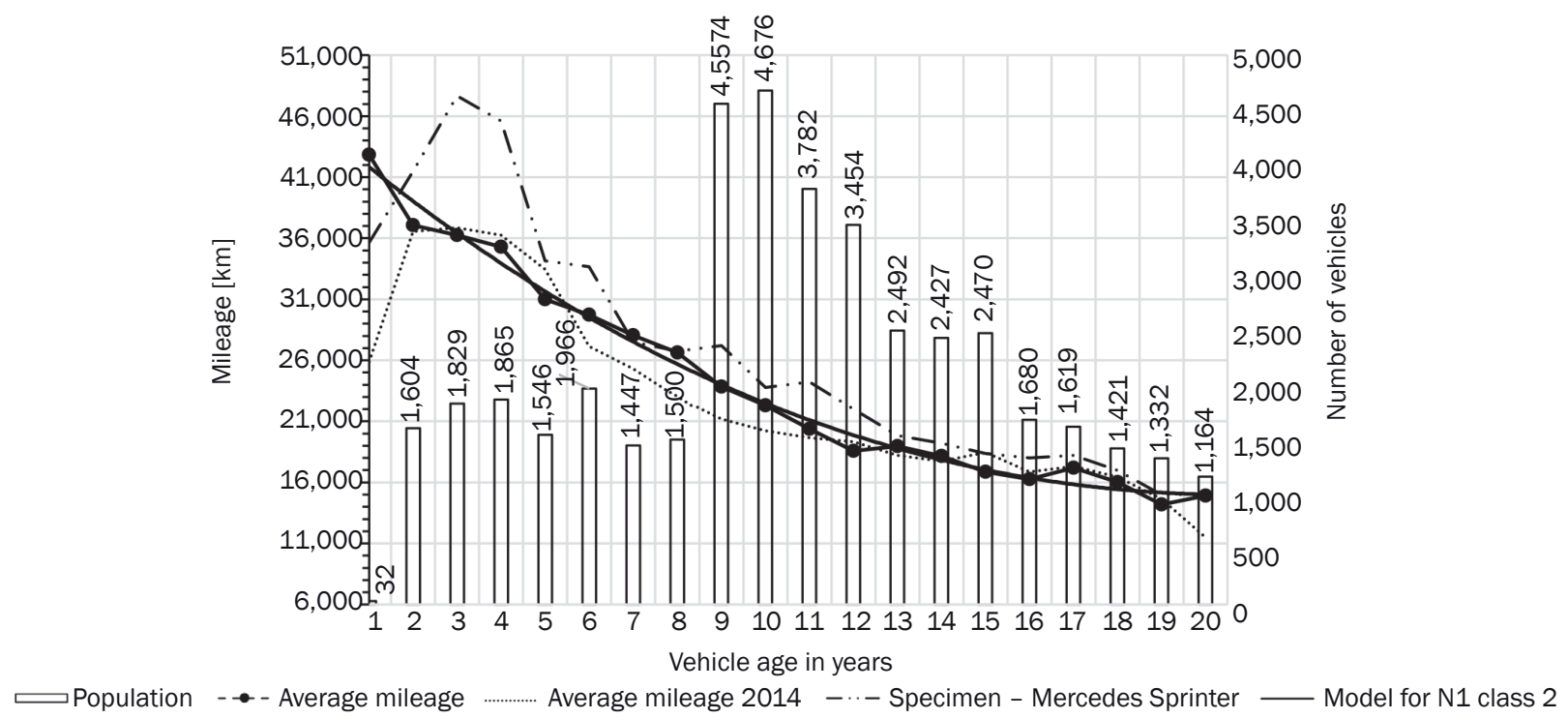

Figure 10 - Average vehicle mileage for category N1 class 2 
fullest potential. The mileage tends to even out in the middle of the life cycle and starts dropping slowly toward the end. The global crisis again has an influence, with a noticeable drop in the number of vehicles aged up to 9 years. The recovery has not started yet because of the cost efficiency of vehicles in N1 class 2 . The specimen for the N1 class 2 is Mercedes Sprinter, and the results for 2014 show its validity.

\subsection{Model applied to N2}

Applying a polynomial regression of the third order $(k=3)$ resulted in an equation with an $R^{2}$ value of 0.9555 . The model applied to N2 is shown in Figure 11 and in Equation 12.

$y=7.9544 x^{3}-262.87 x^{2}+804.23 x+41577$
The resulting model is similar to the N1 class 2 . The specimen for the N2 class is Mercedes Atego, and the results for 2014 show its validity.

\subsection{Model applied to N3}

Applying a polynomial regression of the third order $(k=3)$ resulted in an equation with an $R^{2}$ value of 0.9719 . The model applied to N3 is shown in Figure 12 and in Equation 13.

$$
y=27.991 x^{3}-754.32 x^{2}-92.516 x+106795
$$

The resulting model is similar to the $\mathrm{N} 1$ class 2 and N2. This class has the biggest drop in vehicle mileage throughout the vehicle usage period. The mileage drops to $20 \%$ of the initial vehicle mileage at the end of its life cycle. The specimen for the N3 class model is Mercedes Actros, and the results for 2014 show its validity.

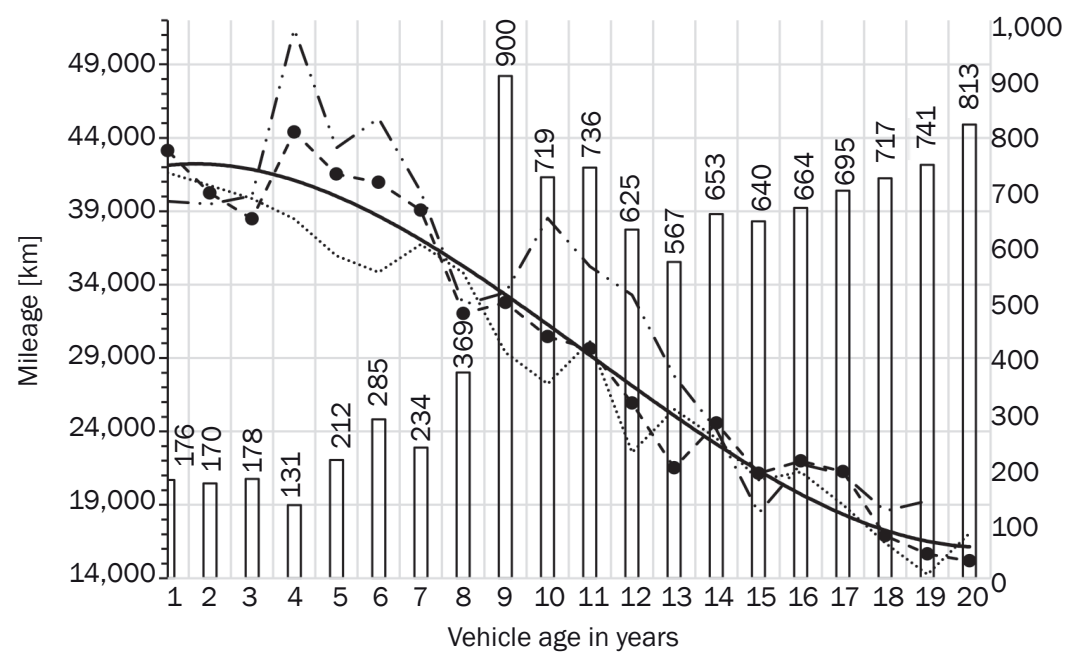

Figure 11 - Average vehicle mileage for category N2

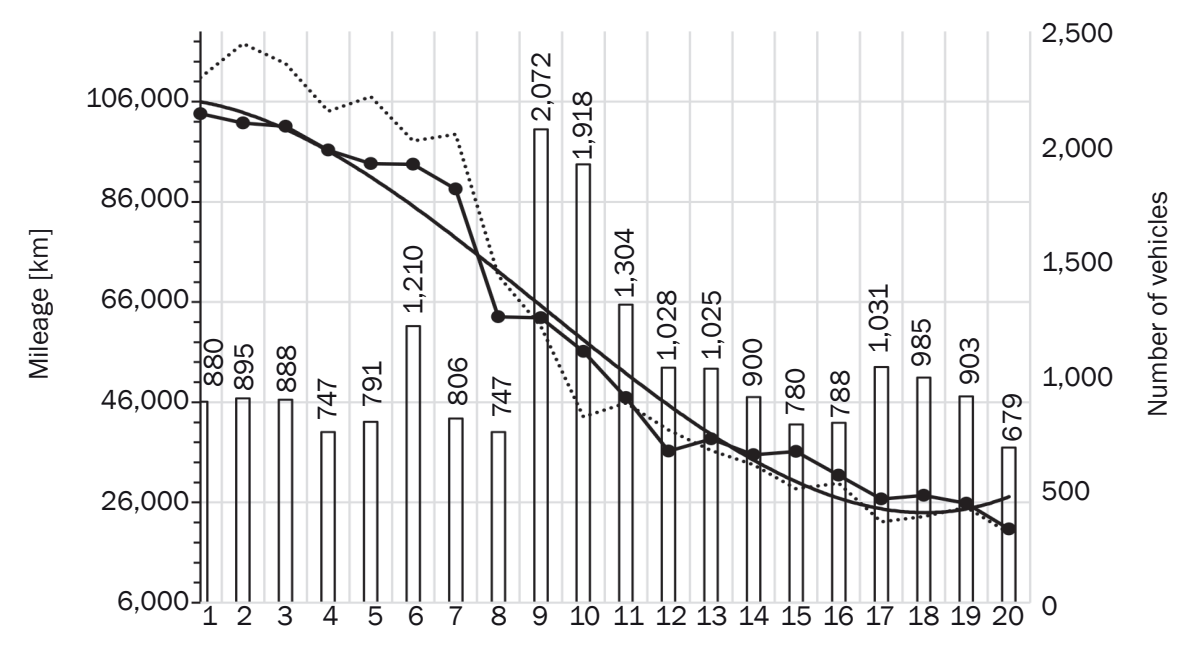

Vehicle age in years

Figure 12 - Average vehicle mileage for category N3 


\section{DISCUSSION}

An existing estimation-based model of another country [16] was compared with real data from Croatia. Data from two countries with different driving fleets, driving behaviors, different road infrastructures cannot be directly compared, but they can reflect the key differences. The comparison was done to show the need for a mileage model in Croatia. The Small ICE-Petrol class from the existing model is comparable to the M1 class 2; the Medium/Large ICE - Petrol class is comparable to the $\mathrm{M} 1$ class 4; the Small/Medium/ Large ICE - Diesel is comparable to the M1 class 3; and the LCV - Diesel/Petrol is comparable to the N1 class 2. Comparing the two models showed that vehicles in Croatia considerably exceed the estimated annual mileage in the years following first registration of the vehicle. A comparison is shown in Figure 13.

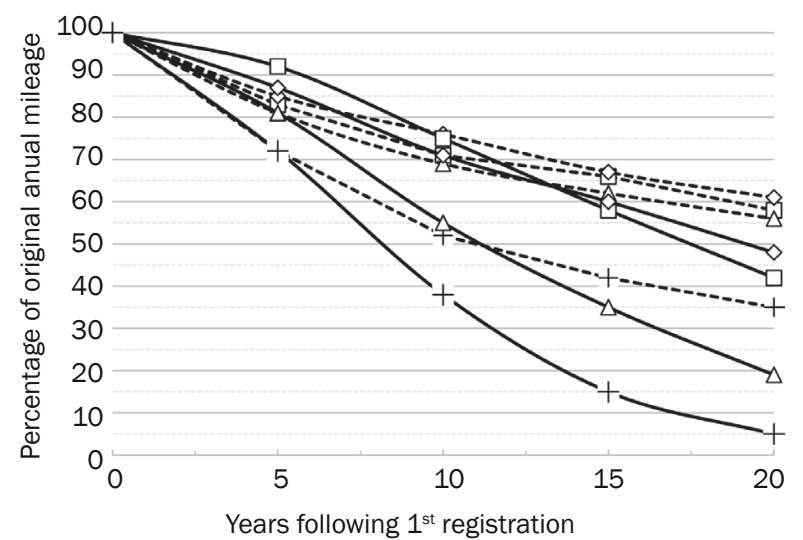

$$
\begin{array}{ll}
-\square-- \text { M1 2. group } & -\checkmark-M 1 \text { 4. group } \\
--\triangle-- \text { M1 3. group } & ---- \text { N1 2. group } \\
-\square-\text { Small ICE-Petrol } & \sim \text { Medium/Large ICE-Petrol } \\
-\triangle-\text { Small/Medium/Large-Diesel } & -+- \text { LCV ICE-Diesel }
\end{array}
$$

Figure 13 - Comparison between calculated average mileage drop during exploitation and real data

Comparing the real data results for 2017 with the results for 2014 shows a slight difference, which indicates the need to update the resulting model coefficients after five to ten years.

\section{CONCLUSION}

The goal of this study was to establish as accurately as possible a model for calculating average annual vehicle mileage. The inputs for the model, the vehicle age and fleet sizes are easy to obtain from various government bodies, dealerships, garages etc.

An emission analysis greatly depends on the average annual vehicle mileage. Wrong or inaccurate values could lead to misguided incentives or long-term decisions in planning sustainable transport. The study shows that existing estimated data differ from real vehicle data and the way of their acquisition should probably be improved for other countries or regions as well.
The model was validated by comparing it with the actual data for 2014. Looking at the data collected for that year, the model coefficients should be updated each in five to ten years. Some model coefficients were additionally validated by applying them to a smaller randomly chosen sample within the vehicle class, and therefore proving their applicability and accuracy.

The model is suitable for use in various analyses where mileage is an input, for instance in transportation, vehicle emission calculations, guidelines for incentives in Croatia etc. Countries with similar driving habits and economic status may also find this model and its coefficients applicable. As for other countries, model coefficients should be tested on samples to determine their viability.

Mr. sc. GORAN PEJIĆ, dipl. ing. stroj. ${ }^{1}$

E-mail: goran.pejic@cvh.hr

FRANJO BIJELIĆ, mag. ing. mech. ${ }^{1}$

E-mail: franjo.bijelic@cvh.hr

Prof. dr. sc. GORAN ZOVAK, dipl. ing. stroj. ${ }^{1}$

E-mail: goran.zovak@cvh.hr

Prof. dr. sc. ZORAN LULIĆ, dipl. ing. stroj. ${ }^{2}$

E-mail: zoran.lulic@fsb.hr

${ }^{1}$ Centar za vozila Hrvatske d.d.

Capraška 6, 10000 Zagreb, Hrvatska

2 Sveučilište u Zagrebu

Fakultet strojarstva i brodogradnje

Ivana Lučića 5, 10002 Zagreb, Hrvatska

\section{MODEL ZA IZRAČUN PROSJEČNE KILOMETRAŽE ZA RAZLIČITE RAZREDE VOZILA TEMELJEN NA STVARNIM PODACIMA: STUDIJA SLUČAJA HRVATSKE}

\section{SAŽETAK}

Podaci o prijeđenim kilometrima dobiveni putem upitnika, izvještaja servisa i sličnih izvora temelje se na procjeni i znatno se razlikuju od stvarnih podataka. Podaci o prosječnoj kilometraži koriste se za izračun emisija, a trebaju biti što točniji kako bi i konačni emisijski model bio pouzdaniji. U Hrvatskoj se stanje putomjera očitava jednom godišnje za vrijeme obavljanja redovnog tehničkog pregleda vozila. Analizirani su podaci stanja putomjera vozila do 20 godina starosti za 2017. godinu. Vozila su razvrstana prema masi praznog vozila i vrsti pogonskog goriva. Podjela prema ovim kriterijima obuhvatila je slične navike vozača kao i svrhu upotrebe tih vozila. Stvarni podaci o stanju putomjera pokazuju kako vozila u Hrvatskoj prelaze znatno više kilometara u razdoblju nakon 10 godina starosti uspoređujući ih s podacima dobivenim iz drugih istraživanja. Istraživanje je rezuItiralo modelom za izračun prosječne prijeđene kilometraže vozila. Model je prikladan za upotrebnu u raznim analizama za Hrvatsku te zemlje sa sličnim voznim navikama i ekonomskim statusom trenutno i u nadolazećim godinama.

\section{KLUČNE RIJEČI}

prosječna kilometraža vozila; model za izračun prosječne kilometraže vozila; redovni tehnički pregled vozila; 


\section{REFERENCES}

[1] European Commission. EU transport in figures - Statistical pocketbook 2016. Luxembourg: Publications Office of the European Union; 2016. Available from: doi:10.2832/809634

[2] Rešetar M, Pejić G, llinčić P, Lulić Z. The influence of passenger car population and their activities on NOX and PM emissions (Data from Croatia). 22 ${ }^{\text {nd }}$ International Transport and Air Pollution Conference, 15-16 November 2017, Zürich, Switzerland; 2017. p. 211-216.

[3] De Ceuster G, et al. TREMOVE: Service contract for the further development and application of the transport and environmental TREMOVE model Lot 1 (Improvement of the data set and model structure. Brussel-Belgium; 2007.

[4] European Commission. Update and further development of transport model TREMOVE - FINAL REPORT, Brussel-Belgium, 2010.

[5] Wilson RE, Anable J, Cairns S, Chatterton T, Notley S, Lees-Miller JD. On the estimation of temporal mileage rates. Procedia - Social and Behavioral Sciences. 2013;80: 139-156. Available from: doi:10.1016/j.sbspro.2013.05.010

[6] Fridstrøm L, Østli V, Johansen KW. A stock-flow cohort model of the national car fleet. Eur. Transp. Res. Rev. 2016;8: 22. Available from: doi:10.1007/s12544016-0210-z

[7] Caserini S, Pastorello C, Gaifami P, Ntziachristos L. Impact of the dropping activity with vehicle age on air pollutant emissions. Atmospheric Pollution Research. 2013;4(3): 282-289. Available from: doi:10.5094/ APR.2013.031

[8] Litman T. Victoria Transport Policy Institute Distance-Based Vehicle Insurance Feasibility, Costs and
Benefits Comprehensive Technical Report, 2001.

[9] Williams V, McLaughlin S, McCall R, Buche T. Motorcyclists' self-reported riding mileage versus actual riding mileage in the following year. Journal of Safety Research. 2017;63: 121-126. Available from: doi:10.1016/j.jsr.2017.10.004

[10] Winslott Hiselius L, Smidfelt Rosqvist L. Segmentation of the current levels of passenger mileage by car in the light of sustainability targets - The Swedish case. Journal of Cleaner Production. 2018;182: 331-337. Available from: doi:10.1016/j.jclepro.2018.02.072

[11] CVH database. https://www.cvh.hr - "access to information"; 2018.

[12] Regulation (EEC) No 4064/89 - Merger Procedure. Case No COMP/M.1406 - HYUNDAI/KIA; 1999. Available from: http://ec.europa.eu/competition/mergers/ cases/decisions/m1406_en.pdf

[13] EUR-Lex. Directive 2007/46/EC of the European Parliament and of the Council. Official Journal of the European Union; 2007. Available from: https://eur-lex. europa.eu/eli/dir/2007/46/oj

[14] Methodology for the calculation of exhaust emissions - SNAPs 070100-070500, NFRs 1A3bi-iv. COPERT Manual.

[15] Mickūnaitis V, Pikūnas A, Mackoit I. Reducing fuel consumption and $\mathrm{CO} 2$ emission in motor cars. Transport. 2007;22(3): 160-163. Available from: doi:10.1080/16 484142.2007.9638119

[16] Trost T, Sterner M, Bruckner T. Impact of electric vehicles and synthetic gaseous fuels on final energy consumption and carbon dioxide emissions in Germany based on long-term vehicle fleet modelling. Energy. 2017;141: 1215-1225. Available from: doi:10.1016/ j.energy.2017.10.006 